\title{
Velferdsteknologi i helse- og oppvekstyrker: Digitalt kompetansebehov i yrkesfaglig utdanning
}

(Welfare technology in health care vocations: Digital competence needs in vocational education)

\section{Solveig Dalehaug Havreberg \& Ann Lisa Sylte}

\author{
OsloMet - Storbyuniversitetet, Norge (soldh@oslomet.no)
}

\section{Abstract}

The fast-paced changes of the Western world community require vocational education and training (VET) that meets the future working-life needs for competence. One challenge in Norwegian health education is the lack of up-to-date teacher competence in welfare technology and digital competence. This article is based on a case study of how vocational teachers in health education programmes $(\mathrm{HO})$ meet the future needs for competence in welfare technology. This research questions what can be changed in VET with these new technologies and how the technology challenges the vocational content of health and education work, and VET. This need for technological competence is also linked to the renewal of curriculum in Norwegian VET, which entails requirements for previous vocational specialisation. The study involved qualitative methods and development experiments. The results show examples of how vocational teachers and students at $\mathrm{HO}$ can meet the future needs for competence in welfare technology related to ethics. The results indicate the need for close collaboration between school and working life to meet the new technology-competence need in the content in both the HO education and the health care occupations. Didactical planned internship in companies using welfare technology, were important for the participants learning about digital tools.

Keywords: vocational digital-teacher-competence, relevant content and teaching, collaboration school - working life, internship 


\section{Introduksjon}

Samfunnet er preget av stor utvikling innen digitalisering og teknologi. I de aller fleste yrker skjer det en omlegging til bruk av digitale hjelpemidler og annen teknologi, noe som også gjelder yrkene innen helsefag i Norge (Helsedirektoratet, 2012). Høsten 2017 ble velferdsteknologi innført som et nytt tema i læreplanen for helse og oppvekstfag i yrkesutdanningen i Norge (Utdanningsdirektoratet [Udir], 2017). Samtidig kan det være utfordrende for yrkesfaglærere å følge med på alt nytt som skjer i arbeidslivet og samfunnet (Dahlback et al., 2019; Hiim, 2017). Både internasjonal og nordisk forskning viser at nær sammenheng mellom skole og bedrift er en forutsetning for relevant yrkesutdanning i tråd med arbeidslivets behov for kompetanse (Billett, 2014; Hiim, 2013; Heggen \& Terum, 2013). Dette kompetansebehovet forsterkes i fagfornyelsen av læreplanverket Kunnskapsløftet i Norge som ble innført i 2020: "Vi fornyer alle læreplanene i skolen for å gjøre dem mer relevante for framtiden" (Udir, 2019, s. 1). Den innbefatter blant annet tydelige krav om tidlig yrkesspesialisering (Udir, 2018). For å imøtekomme utfordringer i yrkesutdanningen gjorde den norske regjeringen tidenes satsning gjennom Yrkesfaglærerløftet med blant annet etter- og videreutdanning for yrkesfaglærere (Kunnskapsdepartementet [KD], 2018). Yrkesfaglærerløftet er et satsningsområde som skal bidra til å øke kvaliteten i yrkesopplæringen, basert på innspill og samarbeid mellom arbeidslivet, skoleeiere, skoler og lærere. Faglig sterke deltakere skal bidra til fag- og yrkesopplæring av høy kvalitet som er tilpasset arbeidslivets behov (KD, 2018).

Dette var bakgrunnen for et tverrfaglig samarbeidsprosjekt mellom utdanningsprogrammene teknologiske fag og helse- og oppvekstfag $(\mathrm{HO})$ ved en yrkesfaglærerutdanning i Norge, med fokus på utvikling av yrkesfaglæreres digitale kompetanse gjennom videreutdanning. Artikkelens fokus avgrenses til programområdet $\mathrm{HO}$ som utdanner deltakere innen eksempelvis barne- og ungdomsarbeiderfaget og helsearbeiderfaget. Artikkelens problemstilling handler om hvordan deltakere ved HO kan imøtekomme fremtidens behov for kompetanse innen velferdsteknologi. Forskningsspørsmålene var: Hvordan utfordrer den nye velferdsteknologien yrkesinnholdet $i$ helse- og oppvekstarbeidet og de yrkesrettede HO-utdanningene? Hva kan endres i yrkesfaglig undervisning med de nye velferdsteknologiene?

Empirigrunnlaget er basert på en casestudie med tre pilotutprøvinger av et videreutdanningskurs for yrkesfaglærere ved $\mathrm{HO}$ i samarbeid med arbeidslivet. Hensikten var at disse yrkesfaglærerne skulle utvikle digital kompetanse gjennom å lære å anvende ny kunnskap om velferdsteknologi i egen undervisning.

Først redegjøres det for endringer i yrkesinnholdet i helse- og oppvekstarbeidet, og videre om velferdsteknologiens implikasjoner for yrkesutdanninger innen $\mathrm{HO}$ knyttet til tidligere forskning og styringsdokumenter. Deretter utdypes metoden før resultatene presenteres og drøftes. Til slutt oppsummeres resultatene med implikasjoner. 


\section{Endringer i yrkesinnholdet i helse og oppvekstarbeidet}

Både Norge og den vestlige verden står foran store utfordringer med "Eldrebølgen" (Bowes \& McColgan, 2009; Helsedirektoratet, 2012). I Norge blir det en økende andel eldre i samfunnet. I 2013 var det 13\% som var over 67 år og det ventes en ytterligere økning til 21\% i 2050 (Helsedirektoratet, 2012). Antall personer med kroniske sykdommer vil øke sterkt. Ifølge Helsedirektoratet (2012) regner man med at antall personer med f.eks. demens vil være ca. 160.000 i 2050. Ut fra disse prognosene vil behovet for utdannede helsefagarbeidere øke sterkt. I dag er det underdekning på ca. 5.000 helsefagarbeidere, mens i år 2035 stipuleres en underdekning på 57.000 helsefagarbeidere (Helsedirektoratet, 2012). Dette er høye prognoser som viser at man må tenke nytt for å kunne hjelpe de eldre i fremtiden. Eldreomsorgen i Japan er et fremtidsrettet eksempel på bruk av nye tekniske hjelpemidler (Husabø, 2018). Husabø (2018) hevder at Japan ligger 20 år foran oss $\mathrm{i}$ å utvikle digitale hjelpemidler og roboter til bruk i eldreomsorgen, noe Norge kan ta lærdom av.

Helsedirektoratet (2012) definerer velferdsteknologi som: "... teknologisk assistanse som bidrar til økt trygghet, sikkerhet, sosial deltakelse, mobilitet og fysisk og kulturell aktivitet, og styrker den enkeltes evne til å klare seg selv i hverdagen til tross for sykdom og sosial, psykisk eller fysisk nedsatt funksjonsevne" (s. 15). Velferdsteknologi kan bidra til å forbedre tilgjengelighet, ressursutnyttelse og kvalitet på helsetjenestetilbudet og dermed fungere som teknologisk støtte til pårørende.

Eksempler på velferdsteknologi kan være digitale journaler på helsefagarbeidernes mobiltelefon, og "smarthus" der ulike sensorer i hjemmet til pasienten registrerer hvor pasienten er og hvem som er i huset. Sensoren kan da registrere om pasienten har falt, hvor beskjed automatisk sendes til hjemmesykepleien. Andre eksempler kan være medisinroboter som varsler pasienten om når medisin skal tas og deler ut ferdigpakket medisin til pasienten. Det blir også brukt digitale skjermer hvor pasientene får informasjon om dagens plan, hvor de også kan kommunisere digitalt med hjemmesykepleiere. Velferdsteknologien er utviklet for at pasientene skal kunne føle seg trygge og sikre hjemme. På den måten kan de bo hjemme lengst mulig. Det legges også vekt på en god livskvalitet for pasienten. Helsefagarbeidere og HO-yrkesfaglærere trenger dermed jevnlig oppdatering av egen digital kompetanse for å håndtere hvordan velferdsteknologien fungerer i de ulike kommunene (Helsedirektoratet, 2012).

Det kan imidlertid være noen etiske utfordringer rundt bruken av denne teknologien. Ifølge Turkle (2018) er ensomhet og personvern hos brukeren et etisk problem hvis det blir for mange tekniske hjelpemidler og roboter i hjemmetjenesten. Det er viktig å ikke glemme personen og dens medbestemmelse når man skal velge hjelpemidler. Videre er det viktig å ta vare på personvernet og taushetsplikten. Det er fortsatt mennesket som er det viktigste, selv om det finnes mange 
tekniske løsninger som kan være gode hjelpemidler (Helsedirektoratet, 2012). For å unngå mange ensomme eldre personer, hvis teknologien overtar mange praktiske oppgaver, vil fremtidens helsefagarbeiders arbeidsoppgaver endre seg fra "tradisjonell pleie" til mer omsorg og kommunikasjon med pasientene, samt teknisk oppfølging av roboter og ladning av hjelpemidler (Husabø, 2018). Erfaring fra slike teknologiske arbeidsoppgaver knyttet til etiske aspekter blir dermed viktig kunnskap som yrkesfaglærere bør utvikle og anvende i egen undervisning.

Samtidig viser både internasjonal og nasjonal forskning at velferdsteknologi kan innebære store muligheter for løsninger innen fremtidens omsorgsutfordringer i helsesektoren (Barlow et al., 2007; Bowes \& McColgan, 2009; Dugstad et al., 2015). Forskning viser at mye av teknologien er på plass, mens utfordringene ligger i manglende kvalifikasjoner til å betjene løsningene, hos helsepersonell. Dugstad et al. (2015) ser et stort behov for å skape interesse og motivasjon hos helsepersonell for å utvikle kompetanse innen velferdsteknologi. Det kan tyde på et reelt opplæringsbehov innen velferdsteknologi i helseutdanningene, hvor også yrkesfaglærere trenger digital kompetanse innen velferdsteknologi. Hvordan dette utfordrer yrkesinnholdet i HO-arbeidet og HO-utdanningene, og hva som kan endres i yrkesfaglig undervisning med de nye velferdsteknologiene, vil denne forskningen bidra med ny kunnskap om.

\section{HO-deltakeres endrings- og kompetansebehov innen velferdsteknologi}

Velferdsteknologien endres raskt, og det kan derfor være utfordrende for yrkesfaglærere å følge med på alt nytt som skjer i arbeidslivet og samfunnet. Derfor er det viktig med et nært samarbeid mellom skole og bedrift for å fremme relevant yrkesopplæring innen HO (Hiim, 2013; Schwencke \& Larsen, 2011). Dette handler om at yrkesopplæringen har fokus på utvikling av relevant yrkeskompetanse for arbeidslivet, noe som vektlegges både i fagfornyelsen 2020, styringsdokumenter og forskning (Dahlback et al., 2018; Jørgensen, 2018; Meld. St. 28, 20152016; NOU 2015:8; NOU 2018:2; Udir, 2018; Wagner, 2008; World Economic Forum, 2018).

Forskning viser behov for bedre yrkesrelevans i yrkesopplæringen der deltakere må styrke egen kompetanse, undervisningen og forankringen til arbeidslivet for å øke utdanningskvaliteten (Billett, 2014; Dahlback et al., 2018, 2019; Hiim, 2017; Jørgensen, 2018). Jørgensens (2018) forskning innen Nordens yrkesutdanninger peker på at manglende oppdatert kunnskap i yrker som er i stadig utvikling, er en stor utfordring som har innvirkning på yrkesfaglæreres kompetansebehov. Tilsvarende utfordringer med økt behov for oppdatert kompetanse for å møte fremtidens helseutfordringer, ses også innen HO (Barlow et al., 2007; Bowes \& McColgan, 2009; Dugstad et al., 2015).

Word Economic Forum (2018) rangerte kompetanse innen kompleks problemløsning som viktigst for 2020. Det ble satt i sammenheng med behovet for blant annet kritisk tenkning, koordinering og samarbeid, emosjonell intelligens, 
dømmekraft og kognitiv fleksibilitet. Tilrettelegging for utvikling av kompetanse innen velferdsteknologi hos helsefaglærere henger nøye sammen med at yrkesfaglærere oppøver evne i slike kompetanseområder. Wagners (2008) forskning peker også på viktigheten av blant annet kompetanse innen problemløsning og kritisk tenkning, samarbeid gjennom nettverk, initiativ og entreprenørskap.

Utfordringen ligger i hvordan yrkesfaglærere kan utvikle sin yrkeskompetanse i tråd med utviklingsbehovet. Billett (2014) fremhever viktigheten av livslang læring, noe som innebærer at yrkesfaglærere kontinuerlig må oppdatere sin yrkesfaglærerkompetanse innen både yrkesfaget, pedagogikk og didaktikk. Billetts (2010) forskning viser at work based learning er nødvendig for å imøtekomme arbeidslivets behov for kompetanse. Schwencke og Larsens (2011) forskning viser imidlertid at arbeidslivet også har nytte av hospitering fordi studenter gjerne bidrar med nye ideer som kan inspirere til innovative utviklingsprosesser. Et viktig mål for dette prosjektet ble dermed å sette søkelys på fremtidens kompetansebehov, som f.eks. evne til komplekse problemløsninger og innovasjon knyttet til ny velferdsteknologi. Dette for å skape interesse og motivasjon for å utvikle kompetanse innen velferdsteknologi hos elever og yrkesfaglærere i $\mathrm{HO}$.

\section{Velferdsteknologiens implikasjoner for yrkesutdanninger innen $\mathrm{HO}$}

Fagfornyelsens læreplan for HO-utdanningen vektlegger stor grad av yrkesfagrelevans og sentrale verdier for HO-yrker (Udir, 2020). Dette bygger på kjerneelementer i yrkene som helse og mestring, kommunikasjon og relasjoner, yrke, etikk og velferdsteknologi, folkehelse og livsmestring, demokrati og medborgerskap, og bærekraftig utvikling. Eksempelvis grunnleggende digitale ferdigheter skal inkluderes gjennom tverrfaglighet der kjerneelementene knyttes til yrkesoppgaver som en helhetlig opplæring i HO-yrker (Udir, 2020). Kjerneelementet velferdsteknologi ses i sammenheng med HO-yrker og etikk. Det innebærer at elevene skal lære å møte mennesker i ulike livssituasjoner med toleranse og respekt. Kjerneelementet handler også om at elevene skal være nysgjerrige og skapende, og utvikle evne til kritisk tenking og refleksjon når det gjelder bruk av velferdsteknologi. Videre handler det om etiske retningslinjer og om verdien av samarbeid med yrkesutøvelsen (Udir, 2020). Dette innebærer et kompetansesyn som innbefatter utvikling av helhetlig yrkeskompetanse. Helhetlig yrkeskompetanse handler om at yrkesutøveren viser evne til å utføre fagarbeid i et yrke og kan løse sammensatte utfordringer knyttet til de enkelte arbeidsoppgaver eller til yrkesutøvelsen som helhet, i tillegg til forståelse og evne til refleksjon og kritisk tenkning (Sylte, 2017a).

\section{Pragmatisk kunnskapsperspektiv som grunnlag for forskningen}

Tilrettelegging for HO-yrkesrelevant opplæring innebærer yrkesdidaktisk planlegging, gjennomføring og vurdering av læringsprosesser med utgangspunkt i yrkesoppgaver og yrkesfunksjoner i helsesektoren (Hiim \& Hippe, 2001). 
Samtidig utfordrer ny velferdsteknologi både innholdet og arbeidsmåtene i dagens yrkesutdanninger innen $\mathrm{HO}$. Selve HO-yrkesoppgaven innbefatter mer og mer digital kompetanse som dermed krever endring i den yrkesfaglige undervisningen. Undervisningsplanlegging med utgangspunkt i yrkesoppgaver med velferdsteknologi der man ser mål, innhold, rammefaktorer, læreforutsetninger, arbeidsmåter og vurdering i relasjon til hverandre, og som en helhet, innebærer et pragmatisk perspektiv på læring (Dewey, 1916; Dreyfus \& Dreyfus, 1986; Hiim, 2013; Schön, 1983).

Forskningstilnærmingen i dette prosjektet tar utgangspunkt i dette pragmatiske læringsperspektivet med fokus på eksperimentell læring gjennom koordinering av egne transaksjoner med omgivelsene - erfaringslæring gjennom prøving og feiling (Dewey, 1916). Da kan både HO-yrkesfaglærere og elever identifisere problemer i yrkesutøvelsen med ny teknologi, prøve ut og koordinere handlinger som kan løse problemet som igjen skaper forståelse og mening. Det kan dreie seg om at yrkesfaglærere/elever reflekterer i og over erfaringen med utprøvinger innen velferdsteknologi (Schön, 1983). Refleksjon i handling er nødvendig når man bevisst prøver ut for eksempel hvordan digital teknologi kan anvendes. Som profesjonell yrkesutøver generaliserer man i form av helhetlige repertoar, ikke $\mathrm{i}$ form av regler og prinsipper. Tolkning og utprøving av ulike situasjoner og evnen til å bruke skjønn er grunnlaget for profesjonell kompetanse. Målet for prosjektet var at yrkesfaglærere og deres elever lærer, ikke bare hva som skal gjøres, men også hvordan, fordi de da vil ha et stort handlingsrepertoar relatert til å kunne skjelne mellom ulike situasjoner som krever ulike handlinger - det innebærer en begynnende ekspertkompetanse (Dreyfus \& Dreyfus, 1986; Sylte, 2016, 2017a).

For at yrkesfagelever skal kunne skjelne mellom ulike situasjoner som krever ulike handlinger, ser Billett (2010) viktigheten av arbeidslivsbasert læring. Hospitering i arbeidslivet kan være eksempel på hvordan både elever og HO-yrkesfaglærere blir en del av et praksisfellesskap, slik det ble gjort forsøk med for yrkesfaglærerne i dette prosjektet. Det er tre prosesser som bør innfris i praksisfellesskapet for at læring kan oppstå (Wenger, 2004). Den første prosessen handler om utvikling av forskjellige former for gjensidig engasjement som for eksempel at yrkesfaglærere/elever bidrar i utprøvinger av velferdsteknologi i arbeidslivet. Den andre prosessen til Wenger (2004) er forståelsen og oppfatning av arbeidsplassen som praksisfelleskap, hvor yrkesfaglærere/elever innordner sitt engasjement på bakgrunn av sin opplevelse i fellesskapet. Her vil de gjøre en innsats for å prøve å forstå arbeidsplassens praksis hvor de for eksempel prøver å finne sin plass i fellesskapet gjennom å delta i velferdsteknologiske yrkesoppgaver. Utvikling av yrkesfaglærere/elevers repertoar, stil og diskurser er den siste prosessen, hvor de prøver å gjenskape meningen med de ulike elementene ved for eksempel å implementere digitale verktøy i yrkesutdanningen og yrkesutøvelsen (Wenger, 2004). 


\section{Metode}

Forskningsstrategien innebar en casestudie der hensikten var å studere didaktiske og sosiale fenomener gjennom en forskningsbasert analyse av tre pilotutprøvinger av et videreutdanningskurs for yrkesfaglærere i perioden 2016-2018. Casestudie er bundet sammen av forskningsspørsmål, fenomen, datainnsamling, analyse og generalisering i en forskningsstrategi (Ramian, 2012, s. 16). Førsteforfatter, med lang erfaring som HO-yrkesfaglærer, erfarte behov for utvikling av innhold og digital kompetanse blant både HO-utdanninger og HO-yrkesfaglærere. Casestudie ble valgt som forskningsstrategi fordi hensikten var ikke å generalisere, men å komme fram til empiriske eksempler som andre lærere og forskere kan dra nytte av. Ifølge Ramian (2012, s. 20) brukes casestudier først og fremst for å beskrive et fenomen for å skape forståelse og å få en dypere innsikt $i$ et komplisert problem som f.eks. deltakernes behov for utvikling av kompetanse innen velferdsteknologi, for å imøtekomme arbeidslivets behov for kompetanse. Førsteforfatter så i likhet med Cochran-Smith og Lytle (1993), fordeler med å forske i egen praksis: "This research recognizes that teacher researchers are uniquely positioned to provide an insider's view that makes visible the way that students and teachers together construct knowledge" (s. 43).

\section{Kontekst}

Casestudien var en del av et større tverrfaglig samarbeidsprosjekt mellom utdanningsprogrammene teknologiske fag og $\mathrm{HO}$ ved en yrkesfaglærerutdanning. Hovedprosjektet innebar et videreutdanningskurs innen ny teknologi for yrkesfaglærere som ble gjennomført ved tre pilotutprøvinger. Dette casestudiet avgrenses til en studie av hoordan yrkesfaglerere ved HO kan imøtekomme fremtidens behov for kompetanse innen velferdsteknologi, implementert som en del av alle tre pilotutprøvingene. Studien av fenomenet avgrenses her til 24 HO-yrkesfaglærere (heretter: deltakere) av totalt 86 yrkesfaglærere som også var studenter ved de tre videreutdanningskursene/pilotutprøvingene. Data fra programområdet teknologiske fag omhandles ikke i denne studien.

Casestudien innebar tre ulike kurs gjennomført som tre pilotutprøvinger over tre semestre, med totalt 18 pedagogiske verkstedsamlinger. Seks av samlingene var nettbaserte. Alle samlingene inneholdt to dagers undervisning. Deltakerne hospiterte i tillegg 30 dager ved ulike arbeidsplasser som f.eks. barnehager og sykehjem som anvender velferdsteknologi. Kursets innhold og undervisnings/ arbeidsmåter hadde fokus på praktisk-teoretisk kunnskap om velferdsteknologi, eksempelvis ulike digitale programmer og VR-briller, som kunne brukes i deltakernes egen undervisning. Arbeidsmåtene var yrkesrettet undervisning, oppgaver og praktiske øvelser med refleksjon i og over yrkesoppgaver som innbefattet digital velferdsteknologi. Mellom samlingene fikk deltakerne nettveiledning om hvordan de skulle skrive digitale logger, blogger og digitale 
historiefortellinger med refleksjon over egen hospitering i bedrift. Målet med hospiteringen var at deltakerne skulle lære ny velferdsteknologi gjennom refleksjon over egne erfaringer, for å kunne anvende den nye velferdsteknologien i egen undervisning. Erfaringene ble presentert i plenum for de øvrige deltakerne på samlingene, og var grunnlag for deres mappeeksamensoppgaver.

\section{Empirigrunnlaget}

Det ble brukt ulike metoder i datainnsamlingen, der alle hadde fokus på problemstillingen og forskningsspørsmålene (se tabell 1).

Tabell 1. Empirigrunnlaget.

\begin{tabular}{|c|c|c|c|c|c|c|}
\hline $\begin{array}{l}\text { Empiri- } \\
\text { grunn- } \\
\text { lag }\end{array}$ & $\begin{array}{l}\text { HO- } \\
\text { deltakere }\end{array}$ & $\begin{array}{l}\text { Forskers } \\
\text { deltakende } \\
\text { observasjon } \\
\text { og deltaker- } \\
\text { logger }\end{array}$ & $\begin{array}{l}\text { Spørre- } \\
\text { undersøkelse/ } \\
\text { kartlegging }\end{array}$ & $\begin{array}{l}\text { Dybde- } \\
\text { intervju }\end{array}$ & Fokusgruppeintervju & Tekstanalyse \\
\hline $\begin{array}{l}3 \text { pilot- } \\
\text { utprøv- } \\
\text { inger av } \\
3 \text { kurs }\end{array}$ & $\begin{array}{l}\text { Totalt } 24 \\
\text { HO- } \\
\text { deltakere } \\
(n=24)\end{array}$ & $\begin{array}{l}18 \text { forsker- } \\
\text { logger og } \\
72(3 \times 24) \\
\text { HO-delta- } \\
\text { kerlogger } \\
(\mathrm{n}=24)\end{array}$ & $\begin{array}{l}\text { kartl. / } \\
\text { spørreunder- } \\
\text { søkelser } \\
\text { HO-deltakere } \\
(\mathrm{n}=24)\end{array}$ & $\begin{array}{l}1 \mathrm{HO}- \\
\text { deltaker }\end{array}$ & $\begin{array}{l}5 \text { gruppeintervju: } \\
(\mathrm{n}=24) \\
\text { HO-deltakere } \\
(2 \times \text { intervju } \mathrm{m} .5+5 \\
\text { HO-deltakere) } \\
(3 \times \text { intervju } \mathrm{m} .5+5+4 \\
\text { HO-deltakere) }\end{array}$ & $\begin{array}{l}24 \text { digitale historie- } \\
\text { fortellinger og } 24 \\
\text { mappeeksamener } \\
\text { (dokumentasjon fra } \\
\text { hospitering) } \\
(\mathrm{n}=24)\end{array}$ \\
\hline
\end{tabular}

\section{Forskers deltakende observasjonslogg}

Førsteforfatter underviste ved kurset, forsket i egen praksis og gjennomførte deltakende observasjon ved samlingene, dokumentert i 18 semistrukturerte logger. Forskerloggene bestod av observasjonsprotokoller og notater fra undervisningen. Fokuset var bruk av digitale verktøy i undervisningen, velferdsteknologi og hvordan deltakerne tilegnet anvendte dette i egen undervisning.

Et problem med bruk av deltakende observasjon kan være innside-/utsideperspektivet ved at man kan bli for nær deltakerne, og man mister verdifull avstand til feltet og dermed en del viktig informasjon i observasjonen (Krumsvik, 2014). Videre kan en feilkilde være at førsteforfatter underviste ved kurset og kunne ha innvirkning på hvordan deltakerne reagerte.

\section{Deltakerlogg}

Deltakerne skrev 72 semistrukturerte logger knyttet til egen hospitering. Fokuset var deltakernes erfaringer med velferdsteknologi på arbeidsplassene som kunne anvendes i deres egen undervisning i skolen.

Spørreundersøkelser / kartlegging

Deltakernes kompetansebehov ble ved hver pilotutprøving kartlagt gjennom totalt tre spørreundersøkelser av 24 deltakere $(n=24)$. Spørreundersøkelsen innebar 
primært kvalitative semistrukturerte spørsmål slik at deltakerne fikk mulighet til å utdype fenomenet, samt noen kvantitative elementer som lukkede spørsmål (Kvale \& Brinkmann, 2015) (se tabell 1). Hensikten var å kartlegge deltakernes kunnskap om velferdsteknologi, hvor mye de brukte digital undervisning før kurset, og hvilke digitale utviklingsbehov de hadde.

\section{Dybdeintervju og fokusgruppeintervju}

I tillegg ble det gjennomført fem fokusgruppeintervju med totalt 24 deltakere for å få ytterligere innsikt i deres erfaringer og opplevelser fra kursene. Fokusgruppeintervjuene ble gjennomført i grupper inndelt etter deltakerenes programområder, to helsearbeiderfag (HEA), barne- og ungdomsarbeiderfag (BUA) og helseog oppvekstfag (se tabell 1). Temaet for intervjuene var bruk av digitale verktøy i undervisningen, velferdsteknologi og nytten av hospitering i bedrifter. Moderatoren var førsteforfatteren. Intervjuene ble gjennomført i en uformell stil for at deltakerne skulle oppleve en trygg atmosfære og dialog med hverandre for å diskutere ulike syn på temaene. Intervjuene ble tatt opp på diktafon.

I fokusgruppeintervju får man fram andre typer informasjon enn ved bare å intervjue de ulike informantene alene. Det positive kan være at fokusgruppen har mulighet til å påvirke intervjuet underveis, mens det negative kan være at moderator kan få for stor innvirkning i prosessen (Krumsvik, 2014).

Førsteforfatter så ytterligere behov for å gå i dybden på fenomenet ved dybdeintervju om en av deltakerne med HEA-bakgrunn sin erfaring med utprøving av digitale verktøy. Det ble først foretatt et preintervju med en semistrukturert intervjuguide for å validere undersøkelsen (Patton, 2015). Deltakeren ga informert samtykke før intervjuet. Intervjuet ble gjennomført på eget rom og tatt opp på diktafon. Det ble gjort fortettinger underveis i intervjuet med avklarings- og oppfølgingsspørsmål for å unngå misforståelser av innholdet.

\section{Tekstanalyse av deltakernes oppgaver}

Deltakerne leverte mappeeksamener som innebar 24 skriftlige oppgaver og 24 digitale historiefortellinger gjennom kurset. Her viste de eksempler på undervisningsopplegg med bruk av digitale verktøy og velferdsteknologi, der de reflekterte over innholdet i kurset og egen kompetanseutvikling.

\section{Analyse, gyldighet og relevans - validitet}

Forfatterne brukte Excel og HyperResearch som analyseverktøy. Analysekategoriene var primært basert på prosjektets pragmatiske kunnskapsteoretiske grunnlag og forskningsspørsmålene. Hovedkategoriene var relevant innhold knyttet til yrkeslivets behov for kompetanse innen velferdsteknologi, yrkesdidaktiske arbeidsmåter i undervisning med underkategoriene digitale verktøy og hospitering $i$ arbeidslivet. 
Dataene ble transkribert og sammenfattet ut fra Kvale og Brinkmanns (2015) tre analysenivåer; selvforståelse, kritisk forståelse basert på sunn fornuft og pragmatisk teoretisk forståelse. Selvforståelse innebar en sammenfatning av deltakernes og forskernes forståelse av det som ble sagt i undersøkelsene. Forskernes kritiske forståelse bygger på den allmenne fortolkningen som har en bredere forståelse enn deltakernes framstilling av fenomenet. Den teoretiske forståelsen var som sagt basert på prosjektets pragmatiske teoretiske ramme i forskernes fortolkning.

Analysen innebar en dekontekstualisering av datamaterialet der forfatterne delte dataene under analysekategoriene. Videre ble datadelene rekontekstualisert i en ny sammenheng, samtidig som forskerne var tro mot de delene av datamaterialet de ble hentet fra. Dette var viktig for gyldigheten. For å unngå at forskerne var suverene i utvelgelsen av empiriske eksempler og tolkning av datagrunnlaget, fikk deltakerne mulighet til å korrekturlese transkripsjonen av datamaterialet og bidra til å korrigere forskernes tolkning. Loggene ble f.eks. analysert for å se om deltakerne hadde brukt nye digitale undervisningsmateriell og velferdsteknologi i sin undervisning i løpet av kurset. Tekstmaterialet, som eksempelvis eksamensoppgavene, ble analysert og vurdert ut fra vurderingskriteriene for de yrkesdidaktiske oppgavene deltakerne presenterte. Vurderingskriteriene innebar at deltakerne skulle synliggjøre hospiteringen i arbeidslivet. De skulle vise bruk av ny teknologi og digitalkompetanse, nye og endrede arbeidsoppgaver, utstyr og metoder i yrkene som kunne gjøres relevante som læringsoppgaver for deres elever i videregående skole.

Forskerne var spesielt bevisste på forskerrollen for å unngå å være subjektive $i$ analysearbeidet. Dette fordi det kan innebære en viss fare for en forutinntatthet og dermed en etisk utfordring i analysearbeidet fordi en av forskerne også var underviser. Deltakerrollen som både yrkesfaglærere og samtidig studenter var avhengige av godkjenning og karakterer fra underviser. Denne avhengigheten kunne representere en viss utfordring for validiteten. Samtidig var forskerne spesielt bevisste på å være nødvendig distansert i forskerrollen i analyseprosessen (Sylte, 2017b) ved at informantene eksempelvis fikk korrekturlese transkripsjonene og utvelgelsen av empiriske eksempler. Det argumenteres for at også metodetrianguleringen bidro til økt validitet gjennom at fenomenet ble belyst gjennom ulike kvalitative undersøkelser.

En mulig svakhet med studien kan være at det kun var 24 deltakerne med HObakgrunn av de totalt 86 deltakende i selve hovedprosjektet som deltok i denne studien. De var dermed noe underrepresentert. Imidlertid argumenteres det for at datainnsamlingen gjennom bruk av ulike kvalitative forskningsmetodene likevel gir et riktig datamateriale til å belyse forskningsspørsmålene og fenomenet på en valid måte. Et annet perspektiv som kan ha påvirket resultatene er at disse deltakerne selv søkte om å delta, og kan dermed representere de mest interesserte lærerne innen teknologi. Samtidig argumenteres det for at disse deltakerne 
bidrar med viktige empiriske eksempler og data som andre lærere kan lære av og dra nytte av. Dermed vil forfatterne hevde at disse deltakernes digitale interesse heller bør ses som en styrke enn en svakhet i dette forskningsprosjektet.

Forskerne informerte deltakerne om prosjektet, at resultatene skulle anonymiseres og at datagrunnlaget ble makulert etter kurset. Deltakerne signerte frivillig på et deltakerskjema. Siden dataene ikke inneholdt personopplysninger, var det ikke nødvendig å registrere prosjektet ved Norsk samfunnsvitenskapelig datatjeneste.

\section{Resultater og drøfting}

Resultatene fra hvordan deltakere ved HO kan imøtekomme fremtidens behov for kompetanse innen velferdsteknologi, blir her presentert og drøftet i lys av deltakernes erfaringer med og opplevelser av fenomenet.

\section{Kompetansebehov}

Deltakernes digitale erfaringer og kompetansebehov var viktig å kartlegge som grunnlag for deres didaktiske tilrettelegging av relevant innhold i egen yrkesutdanning (Hiim \& Hippe, 2001). Resultatene fra spørreundersøkelsene viste at velferdsteknologi var ukjent for de fleste deltakerne. Det var svært få deltakere som brukte f.eks. digitale program som OneNote eller AdobeConnect i sin undervisning, mens noen få hadde høy digital kompetanse. Det samme gjaldt blogg, digitale samhandlingsprogrammer og simulering i undervisningen.

Forventninger om å lære om velferdsteknologi var generelt høye. I spørreundersøkelsene svarte nesten alle at det var fordi det skjer store endringer i arbeidslivet, og at de trenger kunnskapsfaglig påfyll innen eget yrkesområde. Flere reflekterte over viktigheten av å være oppdatert for å kunne drive yrkesrelevant undervisning: "Viktig å undervise i reelle situasjoner - og da er det viktig at vi selv kan bruke velferdsteknologien" (Spørreundersøkelsen). Samtidig uttrykte enkelte ingen forventninger til temaet, noe som kan tyde på digital utrygghet. Eksempelvis sa en deltaker: "Jeg ønsker å lære mer om digitale og interaktive medier og hvordan jeg kan bruke de i undervisningen" (Spørreundersøkelsen).

Tidligere forskning viser imidlertid at velferdsteknologi kan innebære store muligheter for løsninger innen fremtidens omsorgsutfordringer i helsesektoren, men utfordringen ligger i manglende kvalifikasjoner slik de fleste deltakerne her viste ved kursstart (Barlow et al., 2007; Bowes \& McColgan, 2009; Dugstad et al., 2015). Samtidig peker både styringsdokumenter og forskning på samfunnets hurtige endringer der det kontinuerlig blir utviklet nye digitale hjelpemidler, som gjør at ungdommer trenger digital kompetanse i tråd med arbeidslivets behov (Dahlback et al., 2018; Helsedirektoratet, 2012; Jørgensen, 2018; Meld. St. 28, 2015-2016; NOU 2018:2; Udir, 2018, 2019; Wagner, 2008; World Economic Forum, 2018). Resultatene fra både spørreundersøkelsene og tekstanalysene var 
sammenfallende om at velferdsteknologi og digital kompetanse er et viktig og relevant innhold i helse- og oppvekstarbeidet og HO-utdanningene for å imøtekomme arbeidslivets og samfunnets utvikling og behov for kompetanse.

Deltakerne hadde også store forventninger til å lære mer om didaktiske verktøy gjennom dialog og erfaringsdeling, samt arbeidsbasert læring gjennom hospitering i tråd med Billetts (2010) forskning. Wagners (2008) forskning peker på viktigheten av kompetanse innen blant annet problemløsning og kritisk tenkning, samarbeid gjennom nettverk og entreprenørskap, noe som også kom klart fram i analysen av studentoppgavene.

Disse resultatene påpeker viktigheten av at deltakerne trenger nær kontakt med arbeidslivet for å være faglig oppdatert, og tilrettelegge for relevant innhold og yrkesopplæring i tråd med yrkeslivets kompetanse. Resultatene bekrefter nødvendigheten av koherens mellom skole og arbeidsliv (Heggen \& Terum, 2013; Wenger, 2008).

\section{Endringsbehov i HO-utdanninger for å fremme yrkesrelevant innhold og arbeidsmåter}

Hvordan utfordrer den nye velferdsteknologien yrkesinnholdet i helse- og oppvekstarbeidet og de yrkesrettede $\mathrm{HO}$-utdanningene? I fokusgruppe-intervjuene kom det frem at mange deltakere så behov for endring av både innhold og arbeidsmåter i HO. Det var flere forslag om hvordan man kan endre undervisningen. Endringsbehovene presenteres videre i underkapitlene.

\section{Endringsbehov: Digitale verktøy $i$ undervisningen}

Resultatene fra fokusgruppeintervjuene viste at dagens undervisning ved $\mathrm{HO}$ var mest preget av kontekstfri teori inspirert av lærebøker. Underveis i kurset så derimot deltakerne behov for å utvikle praktiske kontekstuelle elevoppgaver med bruk av digitale verktøy og programmer som er relevante for fremtidige HO-yrker. Oppgavene var differensierte slik at elevene kunne velge ulike måter å løse oppgavene på: "noen valgte å lage film, podkast eller tegneserie om hvordan man bryter smittekjeden" (Fokusgruppeintervju). Andre deltakere vektla bruk av praksisrom der elevene kunne øve på bruk av ulike velferdsteknologisk utstyr. Et eksempel var mating av pasient, hvor elevene kunne lære både å mate hverandre og å bruke en materobot. Flere deltakere reflekterte i eksamensoppgavene over mulighetene velferdsteknologien gir både i yrkesutøvelsen og i undervisning. Mange erfarte stor nytteverdi av VR-briller: "å få frem VR/AR-funksjon. Hvis elevene av en eller annen grunn ikke kan være med ute i hjemmesykepleien, har de muligheten å trene visuelt og øve på yrkesutøvelsen likevel" (Eksamensoppgave). Flere skrev at de ville ta i bruk VR-briller i anatomi og fysiologi, og på sikt i prosedyretrening på skolen. Yrkesdidaktisk innhold og arbeidsmåter for å fremme yrkesrelevant $\mathrm{HO}$-utdanning krever yrkesdidaktisk planlegging og gjennomføring med utgangspunkt i HO-yrkesoppgaver som også innbefatter digital 
kompetanse (Helsedirektoratet, 2012; Hiim \& Hippe, 2001; Sylte, 2016; Udir, 2019).

I et fokusgruppeintervju var deltakerne generelt opptatt av varierte arbeidsmetoder som ivaretar elevenes læreforutsetninger: "Man treffer elever som ikke er så motiverte ellers", sa en og reflekterte videre over mulighetene dokumentasjon med bilder/film på mobiltelefon/Ipad kan gi for elever i praksis. Flere fremhevet her viktigheten av at HO-elever reflekterer over egne praktiske erfaringer - erfaringslæring (Dewey, 1916; Schön, 1983): "Da trenger de ikke skrive så mye, men heller vise eksempler fra praksis med video/bilder som dokumentasjon" (Fokusgruppeintervju), sa en deltaker med erfaringer fra elever som dokumenterte praksis på Ipad eller mobilkamera. Dette gir også minoritetsspråklige elever bedre muligheter til å reflektere over egne erfaringer, enn skriftlige oppgaver, sa deltakeren videre.

Derimot så også mange deltakere etiske utfordringer ved bruk av ny velferdsteknologi i både yrkesutøvelsen og HO-utdanningene. En reflekterte i eksamensoppgaven over bruken av spiserobot i omsorgsarbeidet:

Du kan styre den og være selvstendig, men det er nå litt kaldt å bli matet av en robot. Jeg tror ikke du får en eldre person som har dårlig appetitt, til å spise mer ved å bli matet av en "spiserobot". (Eksamensoppgave)

På en annen side så også deltakeren fordeler med spiserobot fordi det kan avlaste helsefagarbeideren slik at det blir mer tid til omsorg og sosial samhandling med beboerne. Ut fra disse resultatene ser forfatterne behov for at HO-elever øver på utvikling av kommunikasjonsferdigheter på skolen, gjennom f.eks. rollespill med "small talk" mellom elever og eldre. På den måten får HO-elever forberede seg på hvordan kommunikasjon og omsorg kan kombineres med velferdsteknologien brukerne har.

Resultatene fra observasjonsloggen viste i praksis at helsearbeidsplasser "henger igjen i gamle tankesett", som en deltaker sa i eksamensoppgaven, og at arbeidsplassen ikke ser nye muligheter og bruksområder for ny velferdsteknologi: "Da må vi gå inn og informere praksisfeltet om den nye teknologien. For å få til dette, må vi ha et tett samarbeid med praksisfeltet for å få det til" (Eksamensoppgave). Mange deltakere ønsket derfor tettere samarbeid med arbeidslivet for å informere om hvordan ungdommer bruker digitale verktøy i skolen (Eksamensoppgave). Samtidig uttrykte mange deltakere stor nytteverdi av selv å anvende digitale samhandlingsplattformer i kurset, som f.eks. operativsystemer som hverken deltakerne eller arbeidslivet hadde stor erfaring med (Observasjonslogg). Dette kan peke i retning av Schwencke og Larsens (2011) forskning som viser at arbeidslivet har nytte av hospitering fordi studenter/elever gjerne bidrar med nye ideer som inspirerer til innovative utviklingsprosesser.

Observasjonsloggene viste imidlertid at deltakerne var opptatt av at bevissthet rundt dataansvarlighet er et viktig innhold i fremtidens HO-utdanninger. En 
reflekterte i studentoppgaven over etiske utfordringer hvor et sykehjem hadde digitale pårørende-sider der bilder om hva som er gjort om dagen ble lagt ut. Deltakeren påpekte viktigheten av å lære HO-elever å innhente tillatelse hos pårørende til å legge ut bilder, fordi det viste seg at det manglet dette sykehjemmet. Etikk knyttet til velferdsteknologi vektlegges også i sterk grad i fagfornyelsens nye læreplaner for 2020 (Udir, 2019, 2020).

\section{Endringsbehov: Hospitering $i$ arbeidslivet}

Hva kan endres i yrkesfaglig undervisning når det gjelder de nye velferdsteknologiene? En deltaker understreket viktigheten av yrkesrelevans ved å lage arbeidslivsbaserte oppgaver i egen undervisning: "Viktig å gjøre undervisningen så praktisk som mulig i yrkesfag. I tillegg bruke teknologien som brukes i arbeidslivet" (Eksamensoppgave). Dette peker på nødvendigheten av nært samarbeid med yrkeslivet i yrkesutdanninger, noe som også var en del av kursets arbeidsmåter i tråd med Billett (2010).

Alle deltakerne erfarte stor nytteverdi hospiteringen som foregikk i Norge, Danmark og Spania innen f.eks. sykehjem, NAV, barnehager og skoler med HOutdanning (Studentoppgaver). I praksisfeltet fikk deltakerne oppdatering om hvordan velferdsteknolog brukes i samfunnet. I fokusgruppeintervjuet med BUA-deltakerne kom det frem at barnehagene bruker mye ny teknologi. Eksempelvis ble Ipad brukt til å registre barna inn/ut, føre fravær/ferier, samt informasjon og fortløpende meldinger til foreldre. De ansattes turnus, pedagogiske planer og aktiviteter ble dokumentert både skriftlig og digitalt i form av bilder i barnehagene. Videre ble Smart Board brukt i samlingsstunden, der de viste bilder til fortellingene eller løste oppgaver sammen med barna. BUA-gruppen var samstemte $i$ at det må vektlegges mer opplæring i bruk av Smart Board og Ipad ved HO-utdanninger.

En annen deltaker så store muligheter ved bruk av VR-briller: "Elevene får en virtuell og virkelighetsnær opplevelse av opplæringen gjennom VR-briller - en slags simulering fordi det gir en realistisk følelse av tilstedeværelse i for eksempel en dataskapt barnehage eller sykehjem" (Fokusgruppeintervju). Denne deltakeren hadde her utviklet egen kompetanse som innovasjon og kompleks problemløsning knyttet til velferdsteknologi i tråd med NOU (2018:2) og Wagner (2008). Samtidig erfarte flere utfordringer med bruk av VR-briller i å finne relevante programmer innen $\mathrm{HO}$ (Eksamensoppgave).

Dette handler om de metodene og begrepene lærere eller elever får lære gjennom hospitering i praksisfeltet, om hvordan de kan påvirke sin opplevelse av erfaringen de får, og som kan gi nytteverdi for fremtiden (Wenger, 2004). I dette kurset fikk deltakerne muligheter til å utforske og ikke bare akseptere tingene som de var (World Economic Forum, 2018). Her undersøkte de muligheter og eksperimenterte gjennom utprøvinger av ny teknologi for å undersøke om den velferdsteknologien egnet seg i deres egen undervisning (Dewey, 1916). 
$\AA ̊$ prøve noe nytt er dristig, men gjennom det nye kan det åpne seg andre veivalg der deltakeren får mulighet til å gjøre nye erfaringer hvor deltakeren ser for seg en annen framtid. For deltakerne var det helt håpløst å kunne se for seg en identitet $i$ et praksisfellesskap om de bare hadde fått informasjon om ny velferdsteknologi i HO-yrkene.

Det kan være vanskelig å vite hvilken kunnskap HO-elever opplever som meningsfull for å utvikle yrkesidentitet. Derfor mente deltakerne at HO-elever må oppleve at de har medvirkning om hvilket innhold som utvikler yrkeskompetanse: "Å bevisstgjøres i hvilke muligheter vi har, hvor viktig det er å utvikle seg innen digitale læringsressurser for elevene og egen del" (Eksamensoppgave). Dette støtter opp om et utviklende og lærende fellesskap (Wenger, 2004).

Resultatene fra studentloggene viste at hospitering bidro til et meningsfullt læringsfellesskap mellom skole og arbeidsliv som var knyttet til deltakernes behov for kompetanse innen velferdsteknologi. Hospiteringen ga et godt utgangspunkt for praksisfellesskap og muligheter for mer utforskende læring (Dewey, 1916). På denne måten ser man på læring som en ressurs for et lærende fellesskap og ikke isolert basert på didaktiske planer som årsak til læring (Wenger, 2004). Erfaringene deltakerne fikk av å jobbe med velferdsteknologi i hospiteringen dannet dermed grunnlag for å lage nye yrkesrettede undervisningsopplegg i deltakernes skoler.

Alle deltakerne opplevde hospiteringen som svært viktig for å lære om velferdsteknologi. En sa i sin digitale historiefortelling: "Viktig å ikke være redd for å prøve ut og være med på nye prosjekter" (Eksamensoppgave). Det er nettopp slik evne til innovativ og kritisk tenkning der både elever og yrkesfaglærere kan utvikle evne til kompleks problemløsning som er viktigst for fremtidens arbeidsliv (World Economic Forum, 2018). Tilretteleggingen gjennom hospiteringen for utvikling av kompetanse innen velferdsteknologi, hang nøye sammen med at deltakerne oppøvde evne til både kompleks problemløsning, koordinering og nettverkssamarbeid (Wagner, 2008).

\section{Digital kompetanseutvikling i undervisning}

Observasjons- og studentloggene viste at deltakerne erfarte stor nytte av kursets innhold om bruk av apper i undervisningen. Appen, Anatomy4D innebærer et AR-program, som kan brukes på mobiltelefon/Ipad, der man kan se kroppen i tredimensjonalt format. Her kan man f.eks. fjerne og legge til ulike organer i kroppen. Hjertet kan ses på nært hold, hjerterytmen kan høres og elever kan se sammentrekkingene når hjertet slår. Dette var nytt for deltakerne og flere uttrykte en "aha-opplevelse" i sine logger. Deltakerne ytret ønske om å ta i bruk programmet som motivasjonskilde $i$ anatomiundervisningen.

Andre reflekterte over nytten av praktiske erfaringer med digitalt arbeid på kurset, der en sa: 
Jeg bruker nå programmer PADLET.COM på Smart Board der elevene skriver inn sine kommentarer. På denne måten får jeg aktivisert alle elevene, til og med den "stille jenta" som er faglig dyktig som aldri tør å si noe høyt i klasserommet.

(Fokusgruppeintervju)

Her reflekterte deltakeren over egen kunnskap om bruk av digital programvare som hun ville bruke videre i egen undervisning.

Digital historiefortelling innebar at deltakerne laget film om sitt nyutviklede undervisningsarbeid der de samtidig reflekterte over planleggingen og gjennomføringen av arbeidet. Deltakerne ble utfordret til å ta i bruk digitale verktøy i egen undervisning, der de fleste utviklet en begynnende ekspertkompetanse gjennom kurset (Dreyfus \& Dreyfus, 1986; Sylte, 2017a).

Et eksempel fra erfaringsdelingen fra de digitale historiefortellingene på kurset: Bruk av VR-briller i undervisningen var nytt for deltakeren. Elevoppgaven handlet om elevers observasjon i en bolig der elevene skulle kartlegge hvilke velferdsteknologiske hjelpemidler de eldre hadde. Deltakeren tok bilder med 360format-kamera i en bolig, som ble lagret på mobiltelefonen via en app kalt, Kuula VR. Mobiltelefonen ble plassert i en VR-brille hvor elevene fikk observere boligen ved å "vandre virtuelt" rundt i boligen. Deltakeren reflekterte entusiastisk: "Elevene blir virkelig ivrige av å oppleve VR-briller, det er en herlig opplevelse for en lærer, minuset er at noen blir kvalme av å bruke brillene" (Eksamensoppgave). Selv om deltakeren kunne se noen etiske utfordringer med personvern ved bruk av bilder fra private boliger som filmgrunnlag, ville deltakeren likevel fortsette med det.

Disse resultatene viser at Billetts (2010) work based learning inspirerte og fremmet læring i hospiteringen. Samtidig viste resultatene at velferdsteknologi kan innebære store muligheter for løsninger innen fremtidens omsorgsutfordringer, ikke bare i helsesektoren, men det kan også innebære digitale hjelpemiddel i helseutdanningene (Barlow et al., 2007; Bowes \& McColgan, 2009; Dugstad et al., 2015).

\section{Fremtidens behov for kompetanse innen velferdsteknologi}

Hvordan kan deltakere ved HO imøtekomme fremtidens behov for kompetanse innen velferdsteknologi? Ut fra spørreundersøkelsen svarte flere deltakere at de ikke brukte mye teknologi i sin undervisning. De fleste brukte kun PC til f.eks. oppgaveskriving. Samtidig kom det fram i fokusgruppeintervjuene at deltakerne er avhengige av å ha gode digitale ferdigheter for å kunne anvende velferdsteknologien. De ønsket seg kurs i ulike dataprogrammer og digitale hjelpemidler. Videre ble det avdekt at skolene trenger oppdatert velferdsteknisk utstyr. Dette kan imidlertid innebære økonomiske utfordringer for skolene.

I fokusgruppeintervjuene kom det frem flere forslag til yrkesfaglæreres kompetanseheving. Ekskursjoner til Hjelpemiddelsentralen kan f.eks. gi yrkesfaglærere/elever informasjon og utprøving av velferdsteknologi. Hospitering i 
bedrifter kan gi yrkesfaglærere/elever opplæring og arbeidserfaring i velferdsteknologi, slik deltakerne i denne studien erfarte. Fordelen med hospiterer er at yrkesfaglærere/elever da får tilgang på det siste nye av teknologi, og i tillegg får øvelse i å anvende utstyret sammen med brukerne. I slike reelle situasjoner med workplace learning (Billett, 2010), får de mulighet til å gjenskape meningen med de ulike elementene innen velferdsteknologi gjennom å anvende teknologien i direkte samhandling med brukerne (Wenger, 2004). I tillegg får de utføre yrkesfaglig arbeid på arbeidsplassen ved å løse sammensatte utfordringer knyttet til velferdsteknologi og yrkesutøvelsen som helhet. Dermed oppøver de forståelse og evne til refleksjon og kritisk tenkning som bidrar til å utvikle helhetlig yrkeskompetanse (Dahlback et al., 2018, 2019; Sylte, 2017a).

Hospitering innebærer imidlertid også ressursmessige utfordringer knyttet til yrkesfaglæreres tid, økonomi og organisering av egen og elevers hospitering (Andersson \& Köpsén, 2017, 2019). Likedan påpeker Aspøy et al. (2017) at kompetanseutvikling som f.eks. hospitering, i liten grad er systematisert. Erfaringene deltakerne hadde med organiseringen av hospitering i denne studien kunne imidlertid variere etter skolens økonomi og deres samarbeid med arbeidslivet. Dette peker i retning av utfordringene tidligere forskning påpeker, nemlig at mange yrkesfaglærere opplever et individualisert ansvar for denne delen av kompetanseutviklingen. Derfor kan det være betimelig å spørre om hvordan en kan systematisere og organisere hospitering, og over økonomiske forhold. Skal f.eks. hospitering medføre lønn for både yrkesfaglærere og praksisveileder? Andre utfordringer med hospitering kan også dreie seg om yrkesfaglærerens tidsressurs til å følge opp egne elever i hospiteringspraksis.

Organiseringen av hospiteringen i denne studien ble imidlertid systematisert gjennom videreutdanningskursets organisering, noe som viste seg å fungere meget godt ifølge deltakerne. Selv om deltakerne måtte finne egne bedrifter å hospitere i, så innebar kursets planer mål og innhold for hospiteringen og hvilke arbeidsmåter de skulle anvende for å lære gjennom denne praksisen. Her viste deltakerne bruk av ny teknologi og digitalkompetanse, nye og endrede arbeidsoppgaver, utstyr og metoder i yrkene som kunne gjøres relevante som læringsoppgaver for deres elever i videregående skole.

\section{Etiske forhold vedrørende velferdsteknologi}

Det kan imidlertid stilles spørsmål rundt de etiske utfordringene ved at velferdsteknologien overtar store deler av arbeidsoppgavene til helsefagarbeidere. Samtidig er teknologisk innhold relevant for fremtidens behov for helsefagarbeiderkompetanse og i HO-utdanninger: "Mulighetene innen teknologi; Ikke for å ta ut menneskelige ressurser, men for å avlaste og ivareta verdigheten hos brukere. Eks: Spyl, tørk toalett og materobot" (Eksamensoppgave). Deltakernes repertoar, stil og diskurser ble utviklet, der de gjenskapte meningen med de ulike elementene ved å anvende ny velferdsteknologi (Wenger, 2004). Deltakerne så derfor 
behov for opplæring i yrkesetiske verdier for elevene. Samtidig var mange deltakere bekymret for at bruk av velferdsteknologi kunne føre til en "kaldere" eldreomsorg. Det kan imidlertid være noen etiske utfordringer rundt bruken av denne teknologien. Det er betimelig å reflektere rundt hvordan brukerne av velferdsteknologien opplever dette. I denne studien er det ikke undersøkt brukernes opplevelse, men deltakernes refleksjoner rundt utfordringene var i tråd med Turkle (2018). Turkle ser nemlig utfordringer som ensomhet og personvern hos brukeren, hvis det blir for mange tekniske hjelpemidler og roboter i hjemmetjenesten.

En deltaker som hospiterte i Danmark syns det var spennende å se hvordan danskene strukturerte hjelpemidler for brukere: "Fremtidens sykehjem hadde fokus på det helhetlige mennesket - menneske var i fokus, ikke økonomi og tid. Dette ble ikke dyrere, men mye mer pasientrettet og inkluderende både for pasienten og ansatte" (Eksamensoppgave). Man kan lett se at slike løsninger vil være $ø$ konomisk samfunnsbesparende, men samtidig må man ikke glemme menneskeverdet opp i all teknologiutviklingen. Derfor er det er viktig å ikke glemme personen og dens medbestemmelse når hjelpemidler skal velges.

I et fokusgruppeintervju ble det diskutert bruken av GPS på brukere, der de fleste argumenterte for at velferdsteknologi er bra for brukeren fordi den får mer selvstendighet i eget liv og kan vandre rundt, mens en annen var skeptisk til "digitale gjerder" som begrenset friheten til brukeren (Fokusgruppeintervju). Her diskuterte deltakerne hvordan de skulle undervise elevene i HO-utdanningen om personvern og etikk. Samtidig vil fremtidens helsefagarbeiders arbeidsoppgaver endre seg fra "vanlig pleie" til mer omsorg og kommunikasjon med pasientene, og teknisk oppfølging av roboter og ladning av hjelpemidler (Husabø, 2018). Dette utfordrer innholdet i både yrkesutøvelsen og HO-utdanningene. Derfor er disse ulike erfaringer fra teknologiske arbeidsoppgaver knyttet til etiske aspekter, viktig kunnskap for deltakerne å anvende i egen undervisning.

\section{Oppsummering og implikasjoner}

Hvordan kan så yrkesfaglærere ved HO imøtekomme fremtidens behov for kompetanse innen velferdsteknologi? Det synes å være mangel på kunnskaper om velferdsteknologi og manglende digitale ferdigheter blant lærere. For deltakere var hospiteringen i videreutdanningskurset, samt opplæring i digitale verktøy og demonstrasjon av VR-briller spesielt viktig for å imøtekomme fremtidens behov for kompetanse innen velferdsteknologi. Samtidig er det viktig å understreke at innhold og arbeidsmåter henger så tett sammen at hospiteringen alene ikke vil gi tilsvarende høyt læringsutbytte innen velferdsteknologi og digital kompetanse, slik disse deltakerne utviklet. Suksessfaktoren for hospiteringen dreide seg om kursets systematiske planer for mål, innhold og hvilke arbeidsmåter de skulle anvende i hospiteringen for å lære gjennom denne praksisen. De digitale 
historiefortellingene og erfaringsdelingen i plenum hadde stor betydning for deltakernes læringsutbytte av hospiteringen. Likedan var det også viktig at deltakerne selv fikk velge hospiteringsbedrift.

Deltakerne fikk dermed et godt grunnlag for å imøtekomme fremtidens behov for kompetanse innen velferdsteknologi. Samtidig er det kontinuerlig endringer, f.eks. den nye velferdsteknologien $i$ arbeidslivet som utfordrer yrkesinnholdet $i$ både helse- og oppvekstarbeidet og de yrkesrettede HO-utdanningene. Dette krever endrings- og utviklingskompetanse blant yrkesfaglærere. Fagfornyelsen i Norge krever samtidig blant annet mer tverrfaglighet, tidligere yrkesspesialisering og helhetlig yrkesopplæring (Udir, 2020). På forskningsspørsmålet om hva som kan endres i yrkesfaglig undervisning med de nye velferdsteknologiene, kom det klart fram i denne studien at nært samarbeid mellom skole og arbeidsliv er en forutsetning. Det er fordi det er i arbeidslivet den nye velferdsteknologien er i bruk og det er der eleven/deltakeren kan oppdatere sin yrkeskompetanse. Samtidig kom det klart fram at et slikt samarbeid må organiseres og systematiseres for å oppnå læring. I kurset ble hospitering vektlagt også for at deltakerne skulle kunne utvikle et godt nettverk som de senere kan bruke i sin skolehverdag, noe som også er en viktig suksessfaktor for å få til samarbeid mellom skole og arbeidsliv. Gjennom erfaringslæringen og refleksjonen i og over egen praksis utviklet disse deltakerne høyere yrkesfaglærerkompetanse gjennom innovasjoner der de viste evne til komplekse problemløsninger (World Economic Forum, 2018).

For noen grupper kan hospitering en uke i året være fint, mens andre vil hospitere i ulike yrker og se på forskjellig utstyr for å sammenligne det som brukes i samfunnet nå. Hospitering kan være en ressursutfordring for skolen. Hvis yrkesfaglærere tas ut av undervisningen en uke i året, krever det resurser i form av lønn til vikarer etc. Noen fylker har satset på etterutdanningskurs for lærere der deltakerne har mulighet til å søke stipend i studietiden. Den norske stat har bevilget penger til kompetanseheving for deltakerne gjennom Yrkesfaglærerløftet. I Norge er det lagt stor vekt på kompetanseheving for yrkesfaglærere, men utfordringen ligger i om det blir en kontinuerlig kompetanseutvikling, at HO-sektoren med både arbeidsliv og utdanning, blir en lærende bedrift der det vektlegges en kultur for kontinuerlig kompetanseutvikling i tråd med fremtidens kompetansebehov.

Det kan konkluderes med at det er ulike behov for ny teknologi i helseyrkene, men samfunnets endringer tvinger fram mer og mer behov for digitale løsninger som både direkte og indirekte påvirker arbeidslivets og utdanningenes behov for kompetanse. En viktig implikasjon er at yrkesfaglærere trenger videreutdanningskurs i digitale ferdigheter, organisert hospitering og et nært og systematisk samarbeid med arbeidslivet for å imøtekomme fremtidens kompetansebehov. Samtidig peker resultatene på viktigheten av at både skole og arbeidslivet tar hensyn til de etiske utfordringer rundt velferdsteknologien, og at det utvikles et 
kritisk syn på fenomenet. Sannsynligheten er stor for at dette gjelder mange elever i yrkesopplæringen, ikke bare i helseutdanninger, men også andre yrkesutdanninger i både Norge og øvrige land.

\section{Om forfatterne}

Solveig Dalehaug Havreberg er universitetslektor ved OsloMet - Storbyuniversitet, Fakultet for lærerutdanning og internasjonale studier, institutt for yrkesfaglærerutdanning helse- og oppvekstfag. Havreberg underviser og veileder i yrkespedagogikk, forebyggende helsearbeid, mat og helsefremmende aktiviteter i helse og oppvekstyrker som inngår i bacheloren Yrkesfaglærerutdanning i Helseog oppvekstfag. Hun har lang erfaring som lektor i videregående skole i Helseog oppvekstfag. Hun forsker i det yrkespedagogiske fagfeltet og er deltaker i aksjonsforskningsprosjektet Lærerutdanningsskoler i yrkesutdanning (LUSY). Hennes forskningsarbeid dreier seg om relevant yrkes- og profesjonsutdanning med vekt på samarbeid mellom skole og arbeidsliv.

Ann Lisa Sylte er FoU-leder/ Ph.D./førsteamanuensis ved OsloMet - Storbyuniversitetet, Fakultet for lærerutdanning og internasjonale studier, Institutt for yrkesfaglærerutdanning. Sylte underviser ved Ph.D.-programmene Yrkespedagogisk forskning og Yrkesdidaktisk forskning. Hun har lang erfaring fra studiet universitets- og høgskolepedagogikk, masterutdanningen i yrkespedagogikk, bachelor i yrkesfaglærerutdanning, samt forskning i det yrkespedagogiske og profesjonspedagogiske fagfeltet. Sylte er instituttets FoU-leder og prosjektleder for LUSY-prosjektet som er støttet av Norsk forskningsråd. Hennes forskningsarbeid dreier seg om relevant yrkes- og profesjonsutdanning som f.eks. didaktiske prinsipper for relevant yrkes- og profesjonsutdanning, yrkes- og profesjonsrettet innhold, arbeidsmåter og vurdering, samt samarbeid mellom skole og arbeidsliv. 
Velferdsteknologi i helse og oppvekstyrker

\section{Referanser}

Andersson, P. \& Köpsén, S. (2017). Maintaining competence in the initial occupation: Activities among vocational teachers. Vocations and Learning, 11(2), 317344.

Andersson, P. \& Köpsén, S. (2019). VET teachers between school and working life: Boundary processes enabling continuing professional development. Journal of Education and Work, 32(6-7), 537-551.

Aspøy, T., Skinnarland S. \& Tønder A. H. (2017). Yrkesfaglærerens kompetanse (Fafo-rapport 2017:11). Fafo.

Barlow, J., Singh, D., Bayer, S. \& Curry, R. (2007). A systematic review of the benefits of home telecare for frail elderly people and those with long-term conditions. Journal of Telemedicine and Telecare, 13(4), 172-179.

Billett, S. (2010). Learning through practice. I S. Billett (Red.), Learning through practice: Models, traditions, orientations and approaches (s. 1-20). Springer.

Billett, S. (2014). The standing of vocational education: Sources of its societal esteem and implications for its enactment. Journal of Vocational Education E Training, 66(1), 1-21.

Bowes, A. \& McColgan, G. (2009). Smart technology and community care for older people: Innovation in West Lothian, Scotland. Age Concern Scotland.

Cochran-Smith, M. \& Lytle, S. L. (1993). Inside/outside: Teacher research and knowledge. Teachers College Press.

Dahlback, J., Olstad, H. B., Sylte, A. L. \& Wolden, A.-C. (2018). Utfordringer og muligheter i møtepunktet mellom yrkesfaglærerutdanningen og pedagogisk praksis i videregående skole. Nordic Journal of Vocational Education and Training, 8(3), 57-77.

Dahlback, J., Olstad, H. B., Sylte, A. L. \& Wolden, A.-C. (2019). Yrkesfaglig lærerkompetanse i brede utdanningsprogram. Scandinavian Journal of Vocations in Development, 4(1), 1-29.

Dewey, J. (1916). Democracy and education: An introduction to the philosophy of education. Macmillan.

Dreyfus, H. L. \& Dreyfus, S. E. (1986). Mind over machine: The power of human intuition and expertice in the era of the computer. Free press.

Dugstad, J., Nilsen, E., Gullslett, M. K. Eide, T. \& Eide H. (2015). Implementering av velferdsteknologi $i$ helse- og omsorgstjenester: Opplæringsbehov og utforming av nye tjenester - en sluttrapport (Skriftserien fra Høgskolen i Buskerud og Vestfold nr. 13). http:/ / hdl.handle.net/11250/285837

Heggen, K. \& Terum, L. I. (2013). Coherence in professional education: Does it foster dedication and identification? Teaching in Higher Education, 18(6), 656669.

Helsedirektoratet. (2012). Velferdsteknologi, Fagrapport om implementering av velferdsteknologi $i$ de kommunale helse og omsorgstjenestene 2013-2030. 
https://www.helsedirektoratet.no/rapporter/implementering-av-velferdsteknologi-i-de-kommunale-helse-og-omsorgstjenestene-2013-2030 Hiim, H. (2013). Praksisbasert yrkesutdanning. Gyldendal Akademisk.

Hiim, H. (2017). Ensuring curriculum relevance in vocational education and training: Epistemological perspectives in a curriculum research project aimed at improving the relevance of the Norwegian VET. International Journal for Research in Vocational Education and Training, 4(1), 1-19.

Hiim, H. \& Hippe, E. (2001). Å utdanne profesjonelle deltagere. Gyldendal Akademisk.

Husabø, B. S. (2018). Japan takler eldrebølgen med roboter. Forskning.no, Universitetet i Bergen. https://forskning.no/partner-universitetet-i-bergen-aldring/japan-takler-eldrebolgen-med-roboter/1244996

Jørgensen, C. H. (2018). Vocational education and training in the Nordic countries: Different systems and common challenges. I C. H. Jørgensen, O. J. Olsen \& D. P. Thunquist (Red.), Vocational education in the Nordic countries: Learning form diversity (s. 1-28). Routledge.

Krumsvik, R. J. (2014). Forskningsdesign og kvalitativ metode- ei innføring. Fagbokforlaget Vigmodstad \& Bjørke AS.

Kunnskapsdepartementet. (2018). Yrkesfaglærerløftet: For fremtidens fagarbeidere. https://www.regjeringen.no/no/tema/utdanning/grunnopplaring/innsiktsartikler/yrkesfagloftet/yrkesfaglarerloftet/id2466578/

Kvale, S. \& Brinkmann, S. (2015). Det kvalitative forskningsintervju (2. utg.). Gyldendal Akademisk.

Lloyd, C. \& Payne, J. (2012). Raising the quality of vocational teachers: Continuing professional development in England, Wales and Norway. Research Papers in Education, 27(1), 1-18.

Meld. St. 28. (2015-2016). Fag - fordypning - forståelse: En fornyelse av Kunnskapsløftet. Kunnskapsdepartementet.

NOU 2008:18. Fagopplæring for framtida. Kunnskapsdepartementet.

NOU 2015:8. Fremtidens skole. Kunnskapsdepartementet. https://www.regjeringen.no/no/dokumenter/nou-2015-8/id2417001/

Patton, M. Q. (2015). Qualitative research E evaluation methods. SAGE Publications.

Ramian, K. (2012). Casestudiet i praksis (2. utg.). Hans Reitzels Forlag.

Schwencke, E. \& Larsen, A. K. (2011). Spenningsfeltet mellom "nytte" for bedriften og "frirom" for studenten: Et samarbeidsprosjekt mellom skole og arbeidsliv for gjensidig påvirkning og ønske om forandring. Nordic Journal of Vocational Education and Training, 1(1), 1-14.

Schön, D. A. (1995). Knowing-in-action: The new scholarship requires a new epistemology. Change: The Magazine of Higher Education, 27(6), 27-34.

Sylte, A. L. (2016). Profesjonspedagogikk: Profesjonsretting/yrkesretting av pedagogikk og didaktikk (2. utg.). Gyldendal Akademisk. 
Sylte, A. L. (2017a). Didaktiske prinsipper for relevant yrkes- og profesjonsutdanning (HiOA Avhandlinger 2017 nr. 11). Høgskolen i Oslo og Akershus.

Sylte, A. L. (2017b). Validitet i aksjonsforskning. I S. Gjøtterud, H. Hiim, D. Husebø, L. H. Jensen, T. H. Steen-Olsen \& E. Stjernstrøm (Red.), Aksjonsforskning $i$ Norge: Teoretisk og empirisk mangfold (s. 443-462). Cappelen Damm Akademisk.

Thisted, J. (2011). Forskningsmetode i praksis: Prosjektorienteret videnskabsteori och forskningsmetodik. Munksgaard.

Turkle, S. (2018). A nascent robotic culture: New complicities for companionship. Massachusetts Institute of Technology.

http://web.mit.edu/sturkle/OldFiles/www/ nascentroboticsculture.pdf

Utdanningsdirektoratet. (2017). LK06: Læreplanverket for Kunnskapsløftet. https://www.udir.no/laring-og-trivsel/lareplanverket/hvordan-er-lareplanene-bygd-opp

Utdanningsdirektoratet. (2018). Ny tilbudsstruktur og nye læreplaner på yrkesfag. https://www.udir.no/laring-og-trivsel/lareplanverket/under-arbeid/nytilbudsstruktur-og-nye-lareplaner-pa-yrkesfag/

Utdanningsdirektoratet. (2019). Fagfornyelsen. https://www.udir.no/laring-og-trivsel/lareplanverket/fagfornyelsen/

Utdanningsdirektoratet. (2020). Læreplan for Vg1 helse- og oppvekstfag. https://www.udir.no/lk20/HSF01-03

Wagner, T. (2008). The global achievement gap: Why even our best schools don't teach the new survival skills our children need - and what we can do about it. Basic Books.

Wenger, E. (2004). Praksisfellesskaber: Læring, mening og identitet. Reitzel.

World Economic Forum. (2018). The future of jobs report 2018. World Economic Forum. 